\title{
EDITORAufmg
}

\section{Nota da autora}

Sônia Queiroz

\section{SciELO Books / SciELO Livros / SciELO Libros}

QUEIROZ, S. Nota da autora. In: Palavra banto em Minas [online]. Belo Horinzonte: Editora UFMG, 2019, pp. 21-22. ISBN: 978-65-8001003-5. https://doi.org/10.7476/9786580010035.0002.

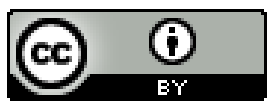

All the contents of this work, except where otherwise noted, is licensed under a Creative Commons Attribution 4.0 International license.

Todo o conteúdo deste trabalho, exceto quando houver ressalva, é publicado sob a licença Creative Commons Atribição 4.0.

Todo el contenido de esta obra, excepto donde se indique lo contrario, está bajo licencia de la licencia Creative Commons Reconocimento 4.0. 


\section{Nota da autora}

No glossário que se segue buscou-se uma forma simples, uma vez que se pretende que a consulta possa abrir possibilidades interpretativas para o leitor. Para muitas palavras foram encontradas diversas ocorrências, que foram anotadas com suas respectivas referências (autor e data). As ocorrências estão separadas em seis blocos: no primeiro, assinalado com um triângulo $\boldsymbol{\Delta}$, estão as palavras encontradas em vocabulários compilados por pesquisadores que buscaram registrar os falares africanos remanescentes em Minas Gerais no século xx; no segundo, assinalado com um triângulo invertido $\boldsymbol{\nabla}$, os nomes de lugares em Minas Gerais; no terceiro bloco, sinalizado por um losango • estão as ocorrências em pesquisas de campo realizadas em outras regiões do Brasil; no quarto, sinalizado por um quadrado - , as ocorrências encontradas em dicionários do português brasileiro e em glossários de livros sobre a presença dos africanos no Brasil, especificamente interessados no que se costuma chamar de "africanismo"; no quinto, assinalado com uma seta — estão os usos desses vocábulos na literatura angolana; e em sexto, assinalado com um círculo •, estão os étimos prováveis, identificados em dicionários de três línguas africanas do grupo banto que predominaram no Brasil: umbundo, quimbundo e quicongo. 
A abertura de verbetes neste glossário partiu da compilação realizada em colaboração com a estudante Amanda Sônia López de Oliveira, publicada pelas Edições Viva Voz, com o título Palavra africana em Minas Gerais. Também abrimos verbetes a partir do glossário de palavras de origem africana encontradas nos contos orais, que integra a tese de Doutorado de Josiley Francisco de Souza, Do canto da voz ao batuque da letra; do levantamento de topônimos realizado por Emanoela Lima na dissertação de Mestrado Toponímia africana em Minas Gerais; e da dissertação de Éverton Machado Simões, África Banta na região Diamantina. Escolhemos para entrada dos verbetes a variante oral registrada mais recentemente. Finalmente, foi necessário realizar uma triagem nos verbetes para excluir palavras que consideramos de origem portuguesa ou iorubá, uma vez que só nos interessam aqui as palavras de origem banto. Excluímos também palavras que não foram encontradas em nenhuma outra fonte pesquisada e sobre as quais não temos nenhuma evidência da origem banto. Em função dessas escolhas, algumas palavras de origem banto usadas em Minas, e mesmo dicionarizadas, como muxoxo, não estão inseridas neste glossário, por não terem registro em nenhuma das fontes usadas para abertura de verbete.

É importante esclarecer ainda que, em algumas passagens da literatura angolana, o autor coloca provérbios ou canções e traz a tradução entre parênteses ou em nota de rodapé. Nesses casos foi preciso colocar todo o texto em língua africana e inserir a tradução feita pelo autor entre parênteses e sem itálico, como é o caso da palavra bambi com o significado de frio. 


\section{Abreviaturas}

euf. eufemismo.

fig. sentido figurado.

interj. interjeição.

lit. literalmente.

olun. olunyaneka.

p. ext. por extensão.

pl. plural.

pop. popular.

port. português.

quic. quicongo e seu conjunto de dialetos.

quimb. quimbundo e seu conjunto de dialetos.

umb. umbundo.

\section{Símbolos}

- Registros de falares, cantos e contos de origem africana em Minas Gerais.

$\boldsymbol{\nabla}$ Registros de nomes de lugares de origem africana em Minas Gerais.

- Registros de falares africanos em outras regiões do Brasil.

- Africanismos registrados em dicionários e glossários brasileiros.

- Registros de palavras africanas na literatura angolana.

- Registros em dicionários de quicongo, quimbundo e umbundo. 